西岡智秀, 南 清和*

\title{
A Case of Occlusal Reconstruction for the Patient with Both of Severe Periodontal Disease and the Anterior Cross Bite.
}

Tomohide Nishioka, Kiyokazu Minami*

There are complicated cases in which mobility is noted in multiple teeth caused by the comprehensive progress of destruction of dental support tissues due to periodontal diseases and secondary biting injuries ; in addition, a pathologic deviation of the lower jaw and an abnormal displacement of the positions of teeth are noted. To those cases, it is essential to design a therapeutic plan based on the comprehensive diagnoses.In order to achieve this, it is most important to use diagnosis waxing up and provisional restoration.

歯周疾患により歯の支持組織の破壞が広範囲に進行し，二次性の咬合性外傷を惹起した 結果, 動摇が多数歯に認められ, なおかつ下顎位の病的な偏位や歯の位置異常が起こって いる複雑な症例は，総合的な診断に基づいた治療計画を立案することが必須である。その ためには，診断用ワクシングとプロビジョナルレストレーションの活用が最も重要である といえる。

Key words：診断用ワクシング diagnosis waxing up, アンテリアガイダンス anterior guidance, バーチカルストップ vertical stop, 中心位 centric relation, LOT Limited Orthodontic Treatment, インプラント implant, ナイトガード occlusal splint, プロビジョナルレストレーション provisional restoration, キーアンド・キーウェイ key \& keyway, 咬合採得 bite registration, 審美 esthetic 

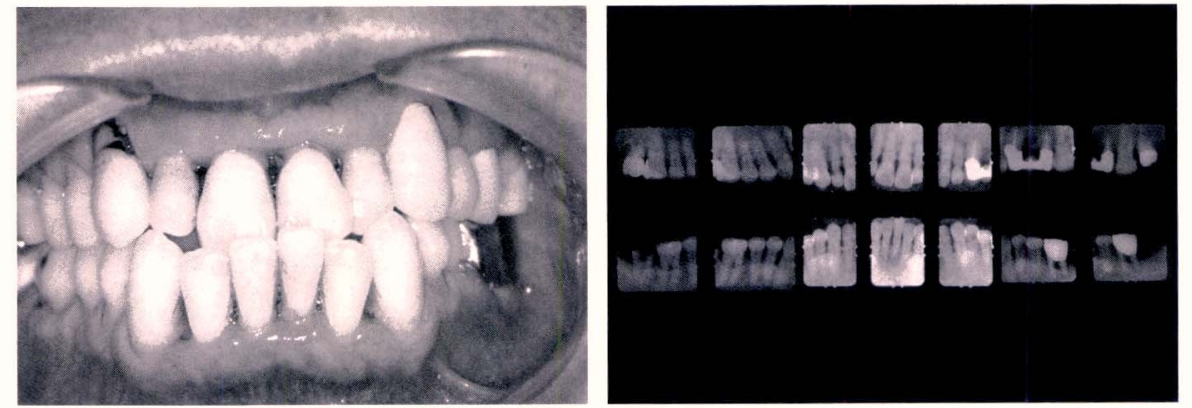

\section{図 1 初診時正面観}

前歯部反対咬合によりアンテリアガイダンス が欠如している. また, 1に早期接触を認める 図2 初診時デンタルX線写真.

水平的な骨吸収が広範囲に存在する，また臼 歯部において垂直的な骨欠損が認められ，咬頭 干渉が疑われる.
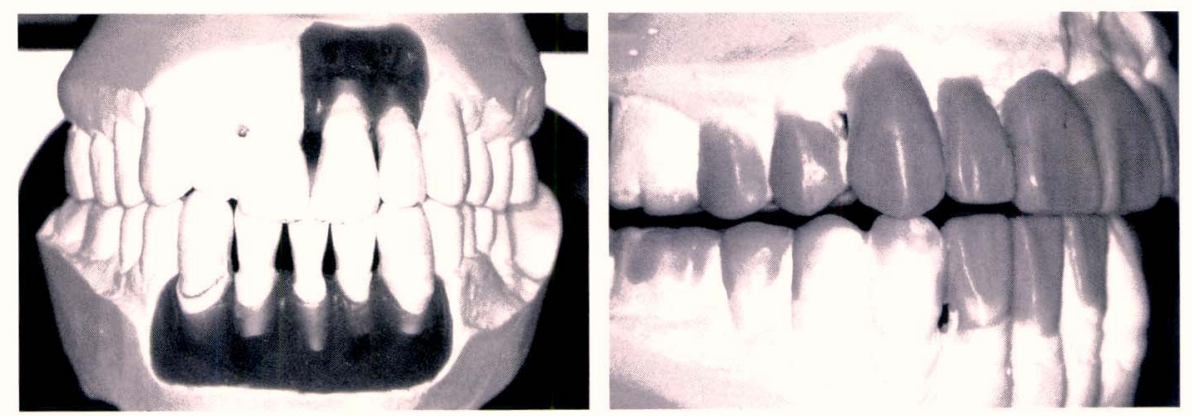

図3 セットアップモデル.

下顎前歯部は早期接触があった1をはずして スリーインサイザルに配列し内方へ移動，12 は舌側転位を歯列弓に並べた。

図4 咬合診断用診断用ワクシング.

セットアップモデルを複印象した模型にワッ クスを添加し, アンテリアガイダンスを与えた.

\section{症例}

患 者：53歳, 男性

初 診: 1998年 2 月 3 日

主 訴：7部の歯髄炎による疼痛

既往歴：特記すべき事項なし

現 症：2〜3力月前より自発痛を認めるが, そのまま放 置. 昨日より拍動性の疼痛を認めたため来院. 約 4 年前が最終歯科受診である。口腔清掃指導・ ス ケーリングの経験はない.

\section{方法}

\section{1. 術式の概要}

患者は7の歯髄炎による疼痛のため来院されたが, 重度 歯周疾患に罹患しており，また，前歯部反対咬合によりア ンテリアガイダンスが欠如している，反対咬合の改善のた め全顎的矯正をすすめたが患者の同意を得られなかった。 今回，中心位にてマウントしたセットアップモデルから一 回目の診断用ワクシングを行い，それを指標に前歯部のみ LOT (Limited Orthodontic Treatment) を行った. 矯正終了後 に二回目の診断用ワクシングにてアンテリアガイダンスの 確立を確認後，プロビジョナルレストレーションへと置き 換えた。バーチカルストップの確立のため左側臼歯部にイ ンプラント補綴を行い, 上顎はキーアンド・キーウエイに よるクロスアーチスプリントとした.

\section{2. 治療経過}

\section{1）初診時の状態}

長期にわたって歯周病に罹患していたため, 歯肉の炎症 と同時に水平的な骨欠損が広範囲に存在する。また前歯部 が反対咬合でありアンテリアガイダンスが欠如しているた め，臼歯部に強い咬合力の影響を受け，垂直的な骨欠損も 見られる (図1，2）。その結果, 多くの歯に強い動摇があ り，各歯が元来の位置を維持できず，臼歯部では，病的な 傾斜と動摇からバーチカルストップが不安定となってお り，現在の咬頭嵌合位は病的に偏位している。顎関節に異 常は認めないが，咬合安定には良好なアンテリアガイダン スが，いかに重要であるかがポイントである。

2）診断用ワクシング

反対咬合改善のために全顎的矯正をすすめたが患者の同 意が得られず，部分矯正ならと何とか承諾を得た。そこで， 現在の咬合状態からアンテリアガイダンスをいかに与える か術前にシミュレーションするため，中心位でマウントさ れたスタディーモデルをもとにセットアップ模型を作成し た(図3)。それを複印象して一回目の診断用ワクシング (primary diagnosis waxing up) を行い, 臨床的指標であるア ンテリアガイダンスを与えた (図4).

3) LOT (Limited Orthodontic Treatment)

セットアップモデルを目標に上顎は左側 2 番の舌側転位 を改善し，下顎は犬歯関係を 1 級関係にすべく両側犬歯を 遠心移動し，早期接触がありバイタル反応もなかった左側 1 番を抜歯し下顎切歯をスリーインサイザルとし内方へ移 


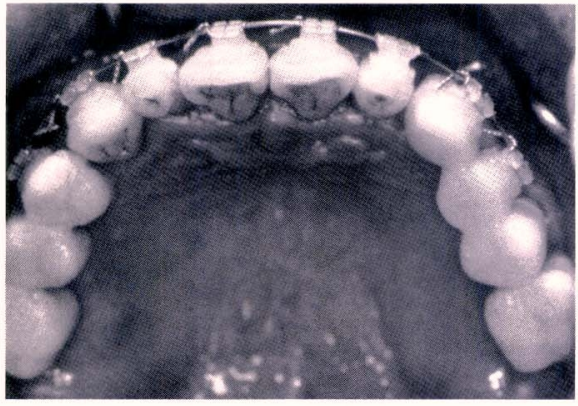

図5 LOT終了時.

セットアップモデルを指標にSRP終了後, LOTを開始した.

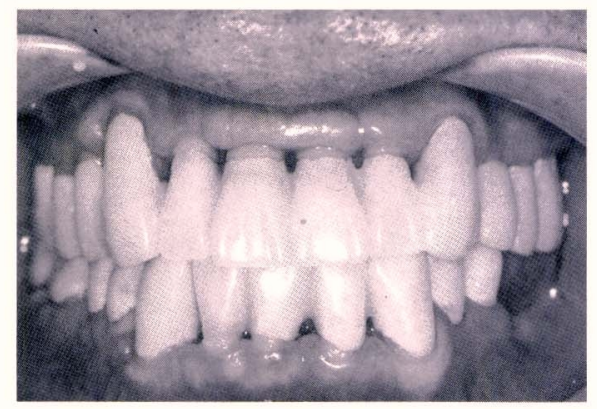

図7 プロビジョナルレストレーションをロ腔 内に装着したところ, 外科処置後のため, 歯肉 は成熟していないが，すべて歯肉緑上でコント ロールしている.

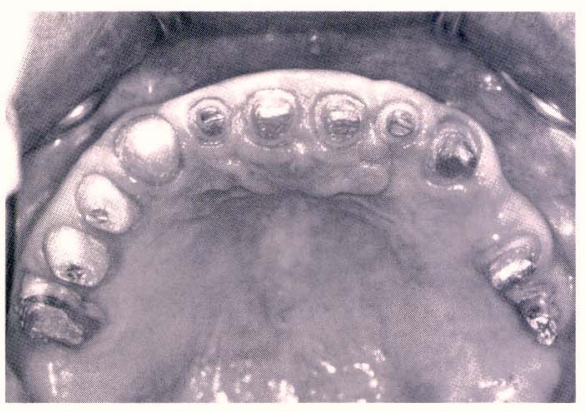

図10.11 最終印象時.

この段階で, 炎症があってはならない.

動した(図5).

4) プロビジョナルレストレーション

複雑な補綴治療を成功に導くキーポイントはプロビジョ ナルレストレーションである。最終補緅へ移行する直前の プロビジョナルレストレーションは材質を除いてすべて最 終補緅物と同一な機能・形態とを持ち合わせていなければ ならない，そこで最終の診断用ワクシング (final diagnosis waxing up) (図6)を行い, プロビジョナルレストレーショ ンを作製する。それをそのまま口腔内に装着し, 機能的に

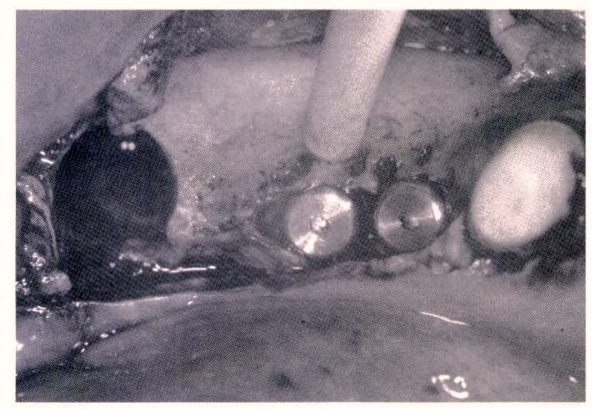

外斜線部より直径 10mmのトレフィンバー にて自家骨を採取して，GBRを併用した。
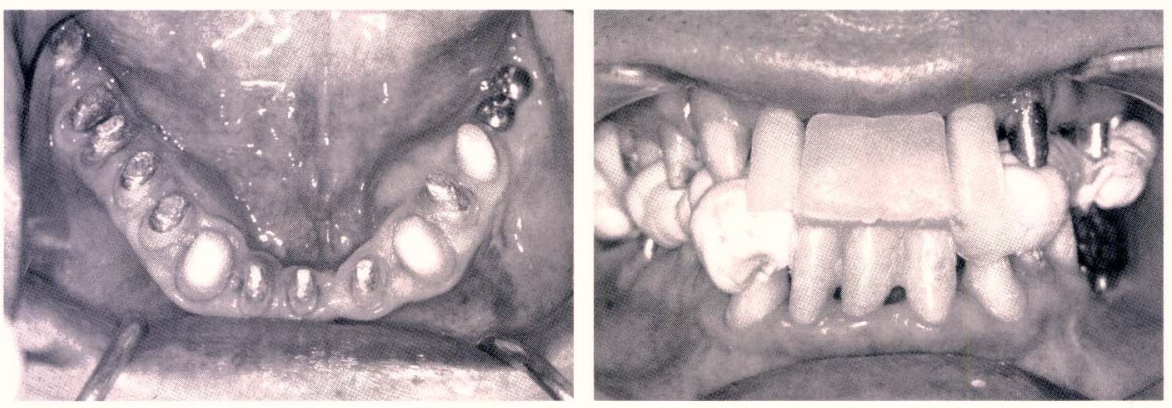

図12 咬合採得.

アンテリアストップワックス法 (アンガイド 変法)にて，CRバイト5つ採得する.
図9 インプラント二次手術.

インプラント部と45部の角化歯肉獲得のた め, 同側口蓋側より遊離歯肉移植を行う

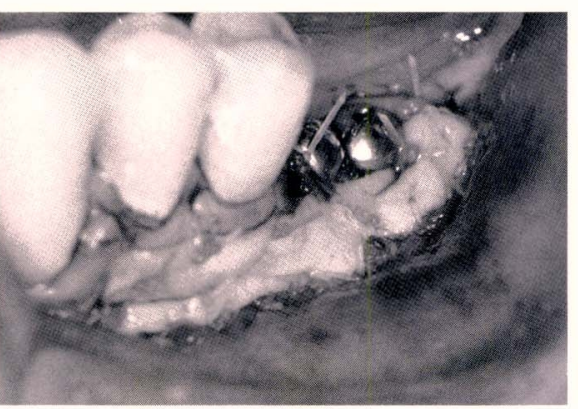

図6 プロビジョナルレストレーション作製の ための診断用ワクシング.

この時点において, 最終補緅と機能・形態が ほぼ同じであることが重要である.

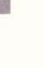



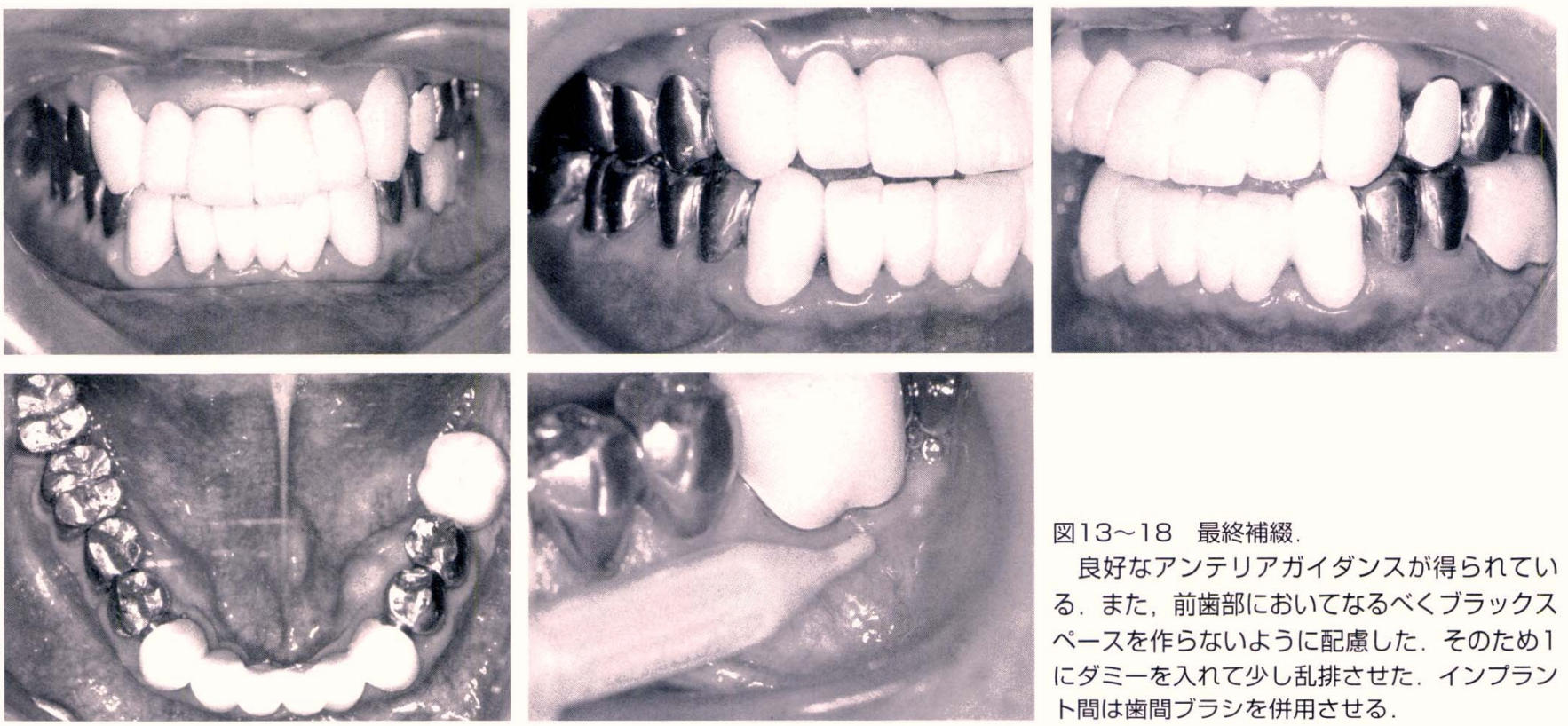

図13〜18 最終補綴。

良好なアンテリアガイダンスが得られてい る.また，前歯部においてなるべくブラックス ペースを作らないように配慮した，そのため1 にダミーを入れて少し乱排させた，インプラン ト間は歯間ブラシを併用させる。
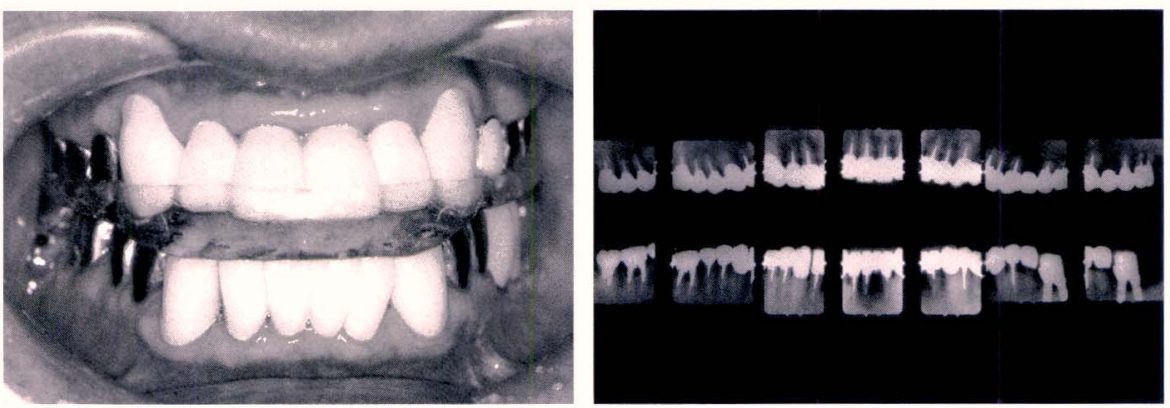

図19ナイトガード.

夜間時のパラファンクションに対応するた め, 必ずナイトガードを装着させる.

図20 術後デンタルX線写真.

骨しベルは水平的に安定しているが，歯冠歯 根比等が改善されたわけではない.

位があれば再評価し, 口腔清掃指導の徹底, プロビジョナ ルの修正を行う。著者らは副歯型式で作製するため, 印象

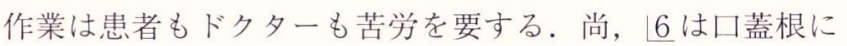
おいて根尖側まで骨吸収が認められたためトライセクショ ンしており，6は根分岐部病変に対応するためにルートセ パレーションしている(図10，11).

7) 咬合採得

咬合採得は中心位で採得するが，著者らはアンテリアス トップワックス法 (アンガイド変法) (図12)にてバイトを 5 つ採得し，スプリットキャストマウント法 ${ }^{5}$ 精度を確認 する.

\section{8）最終補緅}

重度歯周疾患患者に対する補綴治療の問題点として, 審 美的な弱点がある。それには歯の位置異常, 著しく長い歯 冠長，ブラックスペースなどがある，歯頸ラインの不調和 に対して，術前に根面被覆の計画があったが，本症例にお いて微笑時に歯頸部が見えないこと，患者のニーズがな かったこともあり，上顎犬歯はそのまま補緅した。また，
なるべく鼓形空隙を作らないように配慮し，下顎前歯にお いて診断用ワクシングの時点ではスリーインサイザルで計 画していたが歯牙のスペースの問題によりポンティックで 対応した。機能的に関しては良好なアンテリアガイダンス を得ることができた。上顎はクロスアーチスプリントとし て歯列弓の保全に努め, インプラントにより強固なバーチ カルストップを付与することができた(図13〜18). イン プラント部のメインテナンスは歯間ブラシが入るよう配慮 した。また，夜間時のパラファンクションに対応するため に，ナイトガードを装着させている(図19).

\section{結果}

(1)咬合再構成をするにあたり，中心位にて採得した診断用 ワクシングは, 診査・診断・治療に有効であった。

(2)診断用ワクシングで作製されたプロビジョナルレスト レーションは最終補緅の確認とラボコミュニケーション として有効であった。 


\section{考察}

複雑な補綴治療をマネージメントするためには，まず， その症例をあらゆる角度・分野から分析し，一口腔一単位 として症例の全体像を把握し，解決すべき点はどこにある のか，治療のポイントは何かなどの包括的な評価から始め るべきである。そして得られた情報を入念に評価し，総合 的な治療計画を立案する。本症例の一つ目のポイントとし て，初診時に扔ける中心位と咬頭嵌合位の不一致の確認が 重要であるといえる．重度歯周疾患の症例になってくると 歯牙の動摇が強く，下顎位が病的に変位していることが多 い. 二つ目のポイントは診断用ワクシングを必ず行うこと である。診断用ワクシングは基礎資料から得られた情報に 基づく咬合治療・補緅治療の修正プランが全て具体化され ていなければならない。もし，機能・審美面で補緅治療の 範囲を越えていれば，矯正治療への指標となる，本症例に おいても最初の診断用ワクシングのイメージとほほ同様の ものとなり, 術前のシミュレーションがいかに大切かとい うことがいえた。三つ目のポイントとして精度の高いCR バイトを採得することである．CRバイトの採得の方法に は数種類4) あが，著者らはアンテリアストップワックス 法 (アンガイド変法)を用いている，正当な手技を用いれ ば手法はなんでもよいと思うが，そのバイトの再現性が高 くなければならない。そのためにバイトを 5 つ採得 ${ }^{5)} し ，$ スプリットキャストマウント法にてその精度のチェックを 必ず行うようにしている。 たとえば，5つのうち 4 つ一致 すればそのバイトを採用する，その方法により当院におい て大きな問題はでていない，また，このような長期にわた る複雑な治療において一つ一つのステップを確実に行うこ とが重要であり，小さな䛊差が後に大きな誤差として返っ てくる，その中で，基本となる作業がプロビジョナルの取 り扱いであると考える。長期にわたり使用し，修正を繰り 返し行うにあたって，そのつど状況が変化してはならない． 強固で安定したプロビジョナルを維持・管理できるよう に，レジンをうまく使いこなすことが成功への第一歩であ ると考える。

\section{まとめ}

歯周疾患を伴う歯列の修復にあたっては，疾患の活動を 極カコントロールし，歯周疾患に伴う解剖学的歯一歯周組 織の変形に対処しなければならない，若干の違いはあるも のの概念・原則・技術は他の補緅治療を行う場合とほとん ど変わらないが, 治療の成功基準については不明確であり， 複雑な補緅治療によって歯周疾患の予後が改善されるとい う実証は得られていない。長い治療期間，高額な費用，患 者・歯科医師の苦労・大量の歯質削除・歯䯣の犠牲等のリ スクを負うことになるため，予知性が高いものでなければ ならず，あらゆる治療行為の利点・欠点を考慮した上で行 うべきものと思われる。

\section{謝辞}

本症例において御指導していただいた，河津 寛先生を はじめ，大阪SJCDスタッフの皆様，UCLA Henry H. Takei 先生，Perry Klokkevold先生，そして担当技工士の坊川和 義さん, 担当衛生士の溝辺真美さんに心より感謝いたしま す.

\section{参考文献}

1）山崎長郎，本多正明：臨床歯周補綴 III S.J.C.D.創立10周 年記念症例集，11-20，S.J.C.D出版部，東京，1995.

2）山崎長郎：審美修復治療一複雑な補経のマネージメント, 70-76, クインテッセンス出版，東京，1999.

3）保母須弥也, 羽賀通夫，高山寿夫：咬合学. 第 1 版, 5253, クインテッセンス出版, 東京, 1995.

4) Dowson P E：オクルージョンの臨床. 第 2 版, 37-54, 医 歯薬出版, 東京, 1994 .

5）南 清和：包括的歯科医療における治療の流れ。顎咬合 誌, $20(3): 366-375,2000$

6）南 清和, 三浦康志：フルマウスリコンストラクション に扔ける全顎矯正の役割。デンタルエステティックパー 卜 V，第 1 版，145-149，クインテッセンス出版，東京， 1998. 